\title{
Prehistoric Irrigation in Central Utah: Chronology, Agricultural Economics, and Implications
}

\author{
Steven R. Simms (D), Tammy M. Rittenour, Chimalis Kuehn, and Molly Boeka Cannon
}

\begin{abstract}
In 1928, Noel Morss was shown "irrigation ditches" along Pleasant Creek on the Dixie National Forest near Capitol Reef National Park, Utah, by a local guide who contended they were ancient. We relocated the site and mapped the route of an unusual mountain irrigation canal. We conducted excavations and employed OSL and AMS ${ }^{14} C$ showing historic irrigation, and an earlier event between $A D 1460$ and 1636. Geomorphic evidence indicates that the canal existed prior to this time, but we cannot date its original construction. The canal is $7.2 \mathrm{~km}$ long, originating at 2,450 m asl and terminating at 2,170 $\mathrm{m}$ asl. Less than half of the system was hand constructed. We cannot ascribe the prehistoric use-event to an archaeological culture, language, or ethnic group, but the 100+ sites nearby are largely Fremont in cultural affiliation. We also report the results of experimental modeling of the capital and maintenance costs of the system, which holds implications for irrigation north of the Colorado River and farming during the Little Ice Age. The age of the prehistoric canal is consistent with a fragmentary abandonment of farming and continuity between ancient and modern tribes in Utah.
\end{abstract}

Keywords: Fremont, American Southwest, Native American agriculture, irrigation, farming, Utah, Colorado Plateau

En 1928, Noel Morss mostró "zanjas de riego" a lo largo de Pleasant Creek en el Bosque Nacional Dixie cerca del Parque Nacional Capitol Reef, Utah, por un guía local que afirmó que eran antiguos. Reubicamos el sitio y mapeamos la ruta de un inusual canal de riego de montaña. Realizamos excavaciones y empleamos OSL y AMS ${ }^{14}$ C que mostraban riego histórico, y un evento anterior entre 1460 y 1636 dC. La evidencia geomórfica indica que el canal existía antes de este tiempo, pero no podemos fechar su construcción original. El canal tiene 7,2 km de largo, se origina a 2.450 my termina a $2.170 \mathrm{~m}$. Menos de la mitad del sistema fue construido a mano. No podemos atribuir el evento de uso prehistórico a una cultura arqueológica, idioma o grupo étnico, pero los más de 100 sitios cercanos son en gran parte de Fremont en afiliación cultural. También informamos los resultados del modelado experimental de los costos de capital y mantenimiento del sistema que tiene implicaciones para el riego al norte del río Colorado y la agricultura durante la Pequeña Edad de Hielo. La edad del canal prehistórico es consistente con un abandono fragmentario de la agricultura y la continuidad entre las tribus antiguas y modernas en Utah.

Palabras clave: Fremont, American Southwest, agricultura Nativa Americana, riego, agricultura, Utah, Colorado Plateau

$\mathrm{T}$ he Claflin-Emerson Expedition of the Peabody Museum at Harvard University explored the area near Capitol Reef National Park (NP) in central Utah in 19281929 (Spangler and Aton 2018). This substantial effort reported by Noel Morss (2009) in 1931 would define the Fremont Culture and conclude that "the Fremont culture is not an integral part of the main stream of Southwestern development," but the "influences which moulded the Fremont culture appear to have been Southwestern" (Morss 2009:77).

A single paragraph in Morss's report describes a trip in 1928 along Pleasant Creek, a perennial stream originating on Boulder Mountain and flowing east through Capitol Reef NP

Steven R. Simms (s.simms@ usu.edu, corresponding author) and Molly Boeka Cannon $\square$ Department of Sociology, Social Work, and Anthropology, Utah State University, Logan, UT 84322-0730, USA

Tammy M. Rittenour — Department of Geosciences, Utah State University, Logan, UT 84322-4505, USA

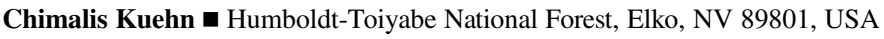

American Antiquity 85(3), 2020, pp. 452-469

Copyright (C) 2020 by the Society for American Archaeology

doi:10.1017/aaq.2020.25 


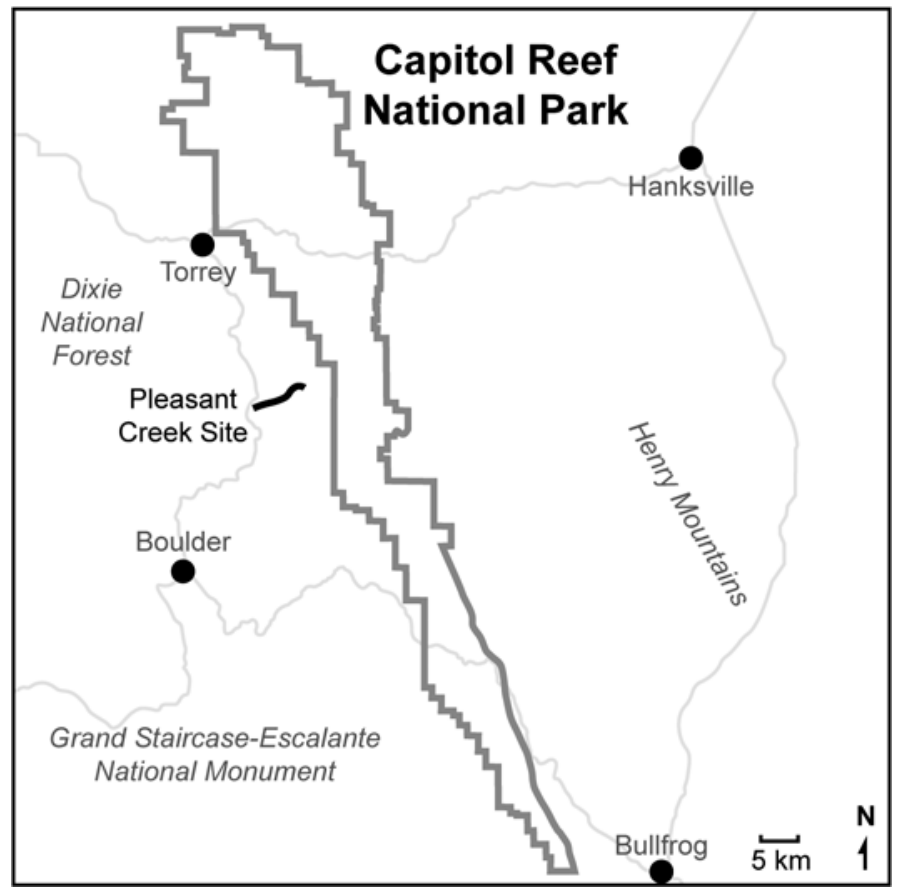

Figure 1. Location of Pleasant Creek site showing local towns and roads and Capitol Reef National Park, south-central Utah.

(Figure 1). The expedition's local guide, Clarence Mulford of Fruita, Utah, showed Morss an irrigation system and argued for its antiquity:

Several intelligent persons bore witness to the existence of an ancient irrigation ditch which could be traced several miles and which had served to bring water from the head of Pleasant Creek onto the flats above. ... It was a shallow depression two feet wide, and looked very similar to the natural channels and sheep trails in the vicinity. ... Our guide was positive [of] its continuity and as to the existence of places showing obviously human handiwork. A few years ago there was a farm on the same flat, since abandoned, which had been irrigated in a similar fashion. ... The ancient ditch showed the lack of modern tools in the way it had been carried around obstructions a modern trench digger would cut through. I am strongly inclined to believe his testimony ... particularly as there is sufficient corn refuse in the Pleasant Creek sites to make it seem probable that farming was carried on.... There are no arable bottom lands, and the practicability of dry farming under present conditions would be very dubious [Morss 2009:7].

The project reported here began in 2010 to relocate what Morss was shown and determine if the claim for antiquity could be supported with evidence. We deviate from Morss's term "ditch" and use "canal" to refer to the transport of water for agriculture, even though this canal is diminutive. We report the results of seven field sessions between 2010 and 2016 along Pleasant Creek, a perennial stream on the Dixie National Forest, about $5 \mathrm{~km}$ upstream from the boundary of Capitol Reef NP (Figure 1). The initial phases of the work are described in a report to the U.S. Forest Service (Simms and Kuehn 2012). We provide additional photographs in Supplemental Materials Sections 2-4. The study reported here includes mapping the route of the system; nine trenches, two of which were expanded horizontally to follow hypothesized 


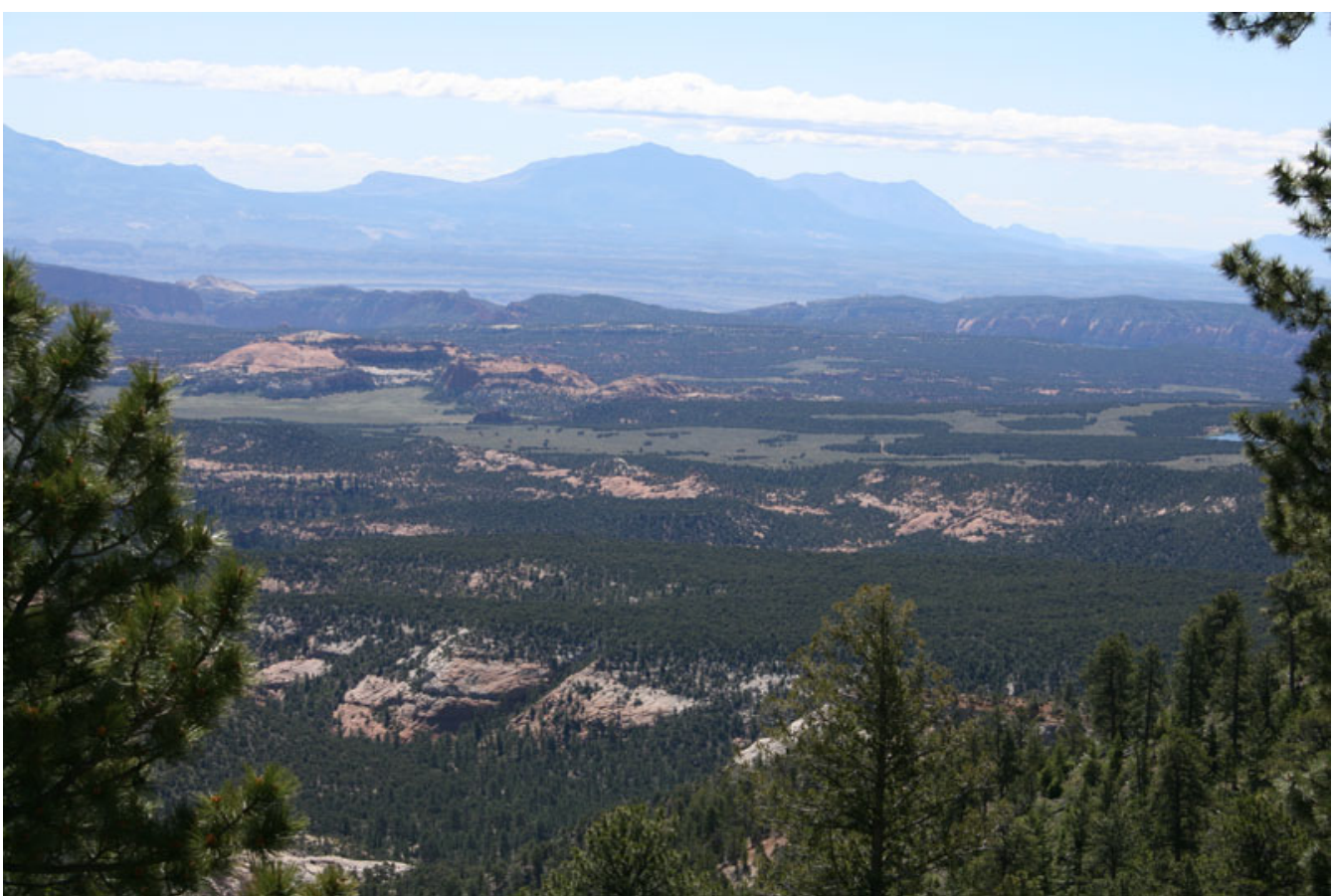

Figure 2. Overview of lower section of irrigation system looking southeast across Capitol Reef National Park toward the Henry Mountains. Jorgenson Flat is the parkland left of center, flanked by Navajo sandstone domes. The canal extends to the right/upslope of Jorgenson Flat across the center of the photo through parkland toward Lower Bowns Reservoir, visible at far right. (Color online)

canals; chronology based on seven optically stimulated luminescence (OSL) dates and one AMS radiocarbon date; remote sensing; and inspection of inventory records for over 100 archaeological sites in the vicinity. We also report the results and implications of a parallel experimental archaeology project modeling the agricultural economics of this type of irrigation system (fully reported in Kuehn 2014).

We introduce our findings here and provide detail in later sections. We were able to locate historic and prehistoric irrigation canals and events. The Pleasant Creek canal (42GA8784) is small at $30 \mathrm{~cm}$ wide and $20-25 \mathrm{~cm}$ deep, and it is capable of transporting only $0.06 \mathrm{~m}^{3}$ of water per second. Water is captured at a subalpine elevation of $2,575 \mathrm{~m}$ and directed $7.2 \mathrm{~km}$ down a fall of over 400 vertical meters to Jorgenson Flat. This open parkland at 2,170 m, which was visited by Morss, is the best available arable land along the canal, offering up to 36 ha for irrigation (Figures 2 and 3). The high elevation of Jorgenson Flat challenges the practicability of farming but has a modern frost-free period of 130-150 days-ample for ancient maize if adequate water is applied.

The system is not pristine. Lower Bowns Reservoir (Figure 4), constructed during the Depression era, was supplied by a diversion that obscured or obliterated the previous historic and prehistoric system(s) above the reservoir. Nevertheless, Morss's argument was strong when he said that water was taken from "the head of Pleasant Creek" because there is no water to take below $2,575 \mathrm{~m}$, the location of the twentieth-century headgate diverting water to Lower Bowns Reservoir.

Below the reservoir, the route of the canal is apparent, and excavations there focused on linear sections where the canal nearly parallels the contours of the slope. Excavations exposed a simple profile of a canal with single-grain OSL ages of broad historic range-cumulatively, AD 17501910. Irrigation sediments typically reflect the final episodes of use, and in the linear sections of canal, earlier use-events within this simple 


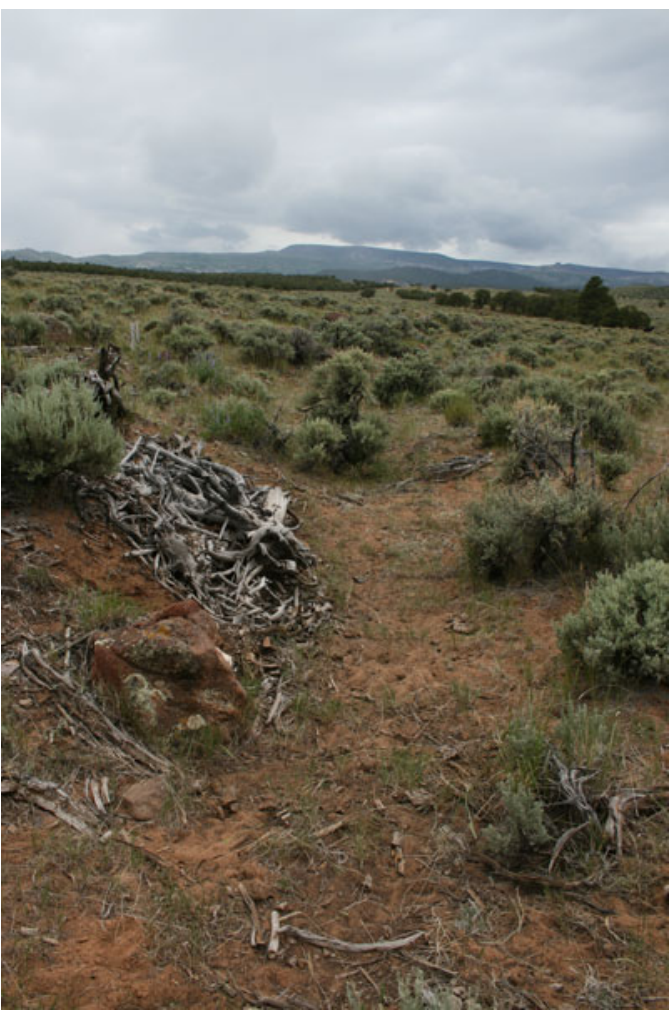

Figure 3. Section of canal grade in vicinity of excavation area looking upstream and west toward Boulder Mountain. (Color online)

single canal would have been disturbed. This leaves some sands from previous events subject to differential bleaching (incomplete solar resetting), yielding a bracket of ages for the latest event that may include partially bleached sands from earlier events mixed with sands aging the latest event.

A contrast to the above sequence was seen along a bend in the canal that was constructed to take the water across a natural drainage. This section required more maintenance and yielded greater stratigraphic complexity. Here, we found a stratified sequence, including an upper depositional package representing historic use-events and a lower depositional package representing an earlier use-event. We sampled the lower canal deposits by targeting quartz-rich laminated sands suggestive of slow, shallow water. A single-grain OSL date produced a range of $\mathrm{AD} 1460-1600$. Directly above this canal was a stratum of massive clumps of charcoal-laden sediments that we interpret as anthropogenic, possibly deposited to adjust the grade. Archaeological charcoal and ground stone along this section of canal was likely the source of the charcoal, uneroded small pieces not deposited in alluvial sediments. AMS ${ }^{14} \mathrm{C}$ on a single piece of charcoal yielded a radiocarbon age of $340 \pm 25$ (K UCIAMS-147406; wood charcoal; $\delta^{13} \mathrm{C}$ not corrected) or cal AD 1492 $1524(p=0.334)$, cal AD 1558-1602 ( $p=$ 0.461 ), and cal AD 1612-1631 ( $p=0.205$; calibrated at $2 \sigma$ with IntCal113.14c [Reimer et al. 2013]) for a $2 \sigma$ range of cal AD 1473-1636. The OSL and radiocarbon dates are statistically identical. Two horizontal excavations, one along a historic canal and another along the prehistoric canal, exposed their morphology and confirmed these are not natural features.

The prehistoric dates do not appear to be the earliest use of the system. At the base of the sequence is an undated $\mathrm{V}$-shaped erosional channel into the ancient substrate that is filled with gravels - a natural alluvial entrenchment event indicating that a canal grade existed here prior to the deposition of the sequence we observe today (prior to $\mathrm{AD}$ 1460). This entrenchment apparently destroyed previous use-events, leaving no way to date the origination of the system.

Experimental archaeology and a study of the agricultural economics found that the cost/ benefit structure of irrigated maize production at Pleasant Creek was within the range of other methods of Fremont/Puebloan maize farming (Kuehn 2014:84-87). We estimate that $3 \mathrm{~km}$ of the $7.2 \mathrm{~km}$ long system was hand constructed and that water was directed down natural fall lines over the remaining $4.2 \mathrm{~km}$. The Pleasant Creek system therefore minimized capital costs while accepting higher maintenance costs.

Our focus here is the age of the prehistoric irrigation event. It is later than the generally recognized terminus of farming in the region. There is, however, an increasing inventory of similar ages on Fremont cultural materials in central and northeastern Utah. Regardless, we refrain from affiliating the irrigation system with any culture, language, or ethnic group because we have no way to make an association. There are 109 recorded sites in a $460 \mathrm{~km}^{2}$ area along 


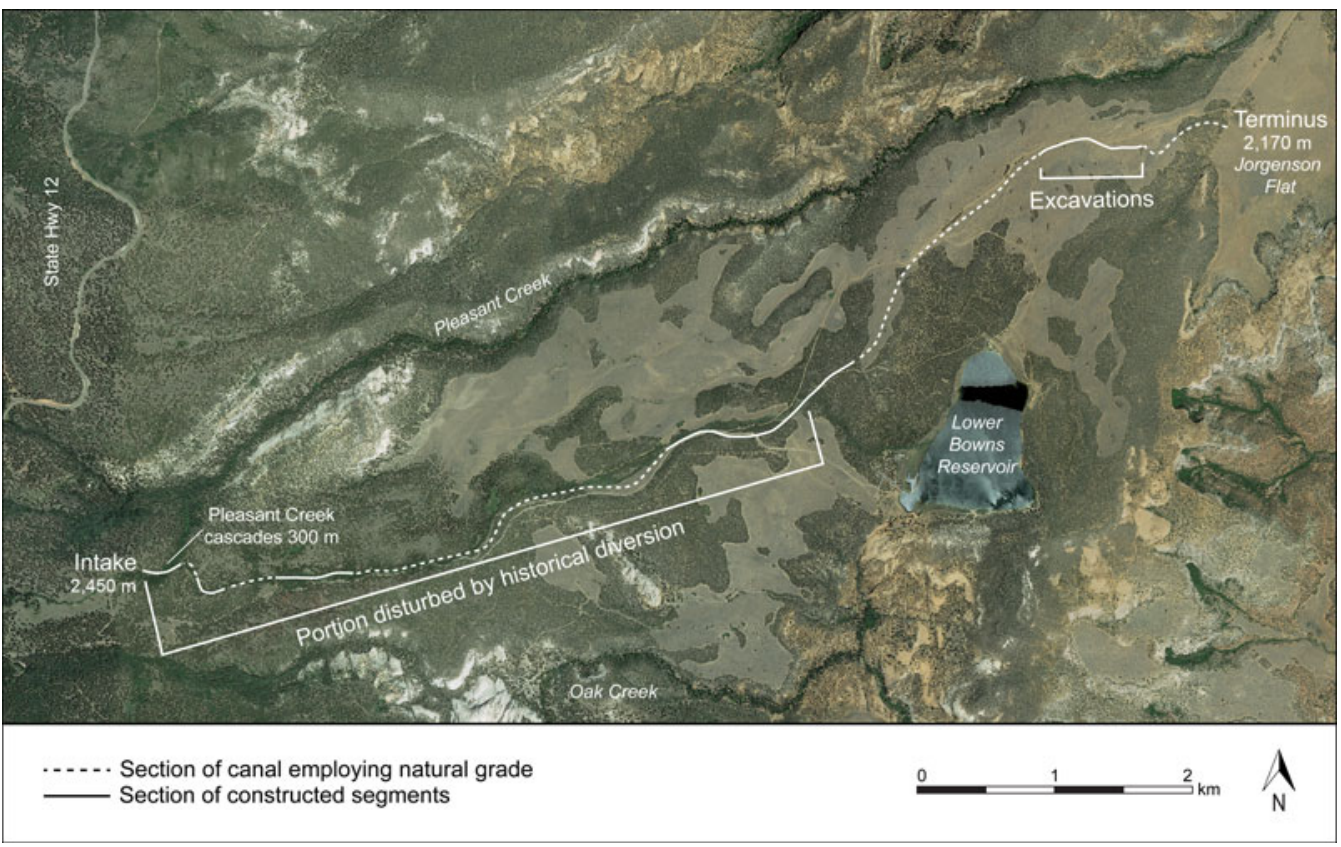

Figure 4. Map of the irrigation system showing places discussed in text. Precise route above Lower Bowns Reservoir is ambiguous. (Color online)

Pleasant Creek, and most are Fremont. Only one is Late Prehistoric. However, we note that proximity of archaeological sites with a canal or field does not equal behavioral association. Instead, we focus on the age of the prehistoric canal to direct attention to questions about the relationship of the ancient and modern tribes, the role of irrigation and agriculture through the transition from the Medieval Climatic Anomaly (MCA) to the Little Ice Age (LIA), and what may have been a fragmentary transition from widespread reliance on agriculture on the Colorado Plateau north of the Colorado River (Lindsay 1986).

\section{The Pleasant Creek System and Context}

\section{Survey of the Pleasant Creek System}

Armed with Noel Morss's description, fieldwork began at Jorgenson Flat. True to Morss's observation, the ancient "ditches" he was shown "looked very similar to the natural channels and sheep trails in the vicinity" (Morss 2009:7). The area near Torrey, Utah (Figure 1), was settled by Euro-Americans in the 1870-1880s, and the floodplain of Pleasant Creek inside what is now Capitol Reef NP was farmed in the 1880s (Kreutzer 2005). The higher terrain west of the park began to be farmed in the twentieth century. In 1928, Morss reported a farm on Jorgenson Flat that had been abandoned "a few years ago ... that had been irrigated in a similar fashion" (Morss 2009:7).

Near Lower Bowns Reservoir (Figure 4), we found obvious small historic canals with intakes located on the diversion to the reservoir (Supplemental Materials Section 5). The reservoir was constructed in stages beginning in 1920 with a small rock dam. Taller dams and a spillway were constructed in the 1930s. Water diverted to the reservoir is at present contained by rock placements and culverts, but the diversions of the 1930s caused dramatic land modification: parallel, now-relict entrenchments in alpine meadows and spectacular dissection on steeper slopes-one of which now harbors a $20 \mathrm{~m}$ tall Ponderosa pine tree dated by coring to about 75 years old (Supplemental Materials Section 4). 
Even though the upper portion of the system is disturbed, topography dictates that to supply water to Jorgenson Flat, the water must be taken from "the head of Pleasant Creek" (Morss 2009[1931]:7) near the concrete headgate at $2,450 \mathrm{~m}$. Only $30 \mathrm{~m}$ beyond this point, native Pleasant Creek cascades hundreds of meters down a 30\% slope into a narrow, entrenched canyon that sequesters the water all the way to Capitol Reef NP. The irrigation canal was routed along the crest of a rocky but flattened ridge of rock outcrops, a range of soil types, and alpine meadows, keeping the water perched between deeply entrenched Pleasant Creek to the north and the equally deep Oak Creek to the south (Figure 4). There is no other water to be taken and no substantial arable land all the way to Jorgenson Flat.

The situation below Lower Bowns Reservoir was different. Here, we found sections of canal on a $2 \%$ grade. Where these terminated, we found small entrenched gullies departing slightly from the canal grade on $4 \%-5 \%$ grades. Each gully originates near the terminus of a constructed canal segment and ends where we find another section of constructed canal. These are the eroded descendants of the natural falls of the irrigation "canal" that once connected constructed segments. The areas where the gullies intercept a constructed section are highly eroded, leaving no evidence of how the intakes were constructed. An absence of rock in these areas suggests there were no substantial dams/barriers, but the amount of water being captured was very small. We can only estimate the extent of hand-constructed as opposed to natural falls, given the disturbance in the upper portion of the system, but the topography and gradients suggest that about $3 \mathrm{~km}$ of the $7.2 \mathrm{~km}$ length of the system was hand constructed.

\section{Archaeological Context}

There are three contexts for the archaeology of the Pleasant Creek site: (1) observations by early residents and archaeologists of suspected prehistoric irrigation canals north of the Colorado River, as well as the archaeological examples of irrigation documented by excavation; (2) the sample of archaeological sites near the Pleasant Creek canal; and (3) the site formation processes shaping the archaeology of irrigation.

Morss's informants were not the only ones to make the claim that nineteenth-century Utah settlers constructed their irrigation systems along the same routes as ancient peoples. James Gunnerson reports in his regional survey of the Fremont, "In several places, the survey was told that early settlers found irrigation ditches near archaeological sites" (1957:5), and specifically for Ferron Creek, central Utah, "The early white settlers are said to have found irrigation ditches just above the mouth of the canyon" (1957:134). Lohse reports, "This author, in conversations with a landowner along Bull Creek, south of Hanksville, Utah, was told that aboriginal fields and ditches were observed when the first Europeans arrived" (1980:49). Albert Reagan reported irrigation "ditches" along Brush Creek in the Uinta Basin (1931a, 1931b:240, 1931c:661, 1931d), in Nine Mile Canyon (1931d, 1931e:46), and in Hill Creek (1931f:226; Spangler 2013:154-155).

Along Hill Creek, in the Tavaputs Plateau region, Reagan observed circular structures (pithouses) and "an ancient village," and as noted by Spangler and Aton (2018:88), "a prehistoric irrigation ditch a half-mile long"-none of which have yet to be redocumented by modern archaeologists.

There are three examples of irrigation known through excavation north of the Colorado River. Near Nawthis Village in central Utah is a "channel" exposed by a land slump. The channel, evaluated as anthropogenic, was constructed on a horizon buried by AD 750 and bracketed by sediments above dated to AD 1300. Nawthis Village was occupied about AD 800-1150 (Metcalfe and Larrabee 1985). Steinaker Gap in northeastern Utah yields several 2-5 m long sections of undated "ditch" (60 $\mathrm{cm}$ wide $\times 25 \mathrm{~cm}$ deep), small dams, and water-control "boxes." Two nearby occupations date to AD 250-400 and AD 700-750 (Talbot and Richens 1996:60-73, 79-82, 188-192). A sinuous $20 \mathrm{~m}$ long undated trench $1 \mathrm{~m}$ deep was found at Median Village, a large agricultural site in the Parowan Valley occupied between AD 950 and 1020 (Marwitt 1970). The original field notes indicate uncertainty as to its purpose, but the trajectory of the 
feature is consistent with an irrigation canal (42IN124 field notes 1968, J. Marwitt; Simms and Bright 2009). Excavator John Marwitt noted similar features at the Nephi and Caldwell Village sites in central and northeastern Utah, respectively.

Morss demonstrated the rich archaeological record along Pleasant Creek above Capitol Reef NP: alcoves with Puebloan (Fremont) architecture, artifacts, and maize cobs. He retrieved collections for the Peabody Museum at Harvard University and observed local private collections of spectacular perishable artifacts (Morss 2009; Spangler and Aton 2018). Kreutzer (2005) summarizes the history and research in Capitol Reef $\mathrm{NP}$, and the most recent large project recorded 472 sites. Test excavations at 25 sites associated with farming cultures found that the "majority" date to AD 500-1050, with some in the "late Fremont period" between AD 1050 and 1400 (Janetski et al. 2005:170). Fremont occupation along Pleasant Creek inside the park was significant where the canyon opened onto a broader floodplain.

Jorgenson Flat and the terminus of the Pleasant Creek canal is from 5 to $10 \mathrm{~km}$ upstream from the concentrations of Fremont sites mentioned above, and in a very different topographic and hydrological situation. State inventory records show 109 archaeological sites in a $460 \mathrm{~km}^{2}$ linear band straddling the Pleasant Creek canal/ Jorgenson Flat areas. Forty-nine sites have cultural affiliations (based on projectile points and ceramics): 43 Fremont, five Archaic, and one Late Prehistoric. We observed large, open Fremont sites with probable pithouses within $1 \mathrm{~km}$ of the lower canal/Jorgenson Flat area. Their proximity to the canal and Jorgenson Flat does not establish behavioral association.

The discovery and documentation of irrigation is fraught with difficulty associated with site formation processes. Use of an irrigation canal destroys or obscures earlier use, causing OSL ages to represent the latest event. On the other hand, OSL samples of last use can include partially bleached sands from previous events, causing the age of last use to appear earlier than it was. Single-grain dating, as was done here, can ameliorate but not eliminate these effects. Remodeling a canal and deposition to reset the grade to maintain proper flow also alters evidence of prior use, as does natural erosion during nonuse periods.

On a regional scale, the topographic and hydrological constraints for irrigation imply that the site selection criteria of nineteenthcentury Euro-American farmers were the same as prehistoric farmers - one reason why early historic farmers saw remnants of earlier canals. The site formation processes of irrigation imply that most of the evidence is destroyed by later irrigation, except under fortunate circumstances. Or, it is buried under towns because the prime farmland was settled first, then urbanized. Consequently, it is likely that ancient irrigation is underrepresented in the archaeological sample. This holds implications for interpreting subsistence and settlement in the prehistoric farming cultures north of the Colorado River.

\section{Excavations and Chronology}

The U.S. Forest Service permitted limited excavations to aid the evaluation of site significance. The excavation area is along the lower stretch of the system where the canal grade is most evident (Figure 5). Nine test excavation trenches, most of them $50 \mathrm{~cm}$ wide $\times 2-4 \mathrm{~m}$ long by approximately $50-70 \mathrm{~cm}$ deep, bisected the canal grade. Two trenches were expanded horizontally to investigate canal morphology.

Chronology is based on seven OSL dates and one AMS radiocarbon date. Single-grain OSL dating was used and has proven to be successful in other cases of prehistoric irrigation features (e.g., Huckleberry and Rittenour 2014). Sample analysis followed the single-aliquot regenerativedose procedure for single-grain and small-aliquot OSL dating (Duller 2008; Murray and Wintle, $2000)$. Equivalent dose $\left(D_{E}\right)$ values were calculated using the minimum age model (Galbraith and Roberts, 2012) on single-grain data to reduce the influence of partial bleaching (incomplete solar resetting) on the resultant $\mathrm{D}_{\mathrm{E}}$ and age. Samples were collected in opaque metal tubes targeting sediments near the base of the canals with structures indicating shallow water deposition and avoiding bioturbated sediments. The primary geological source of the sands found in the canals is quartz-rich Navajo sandstone, 


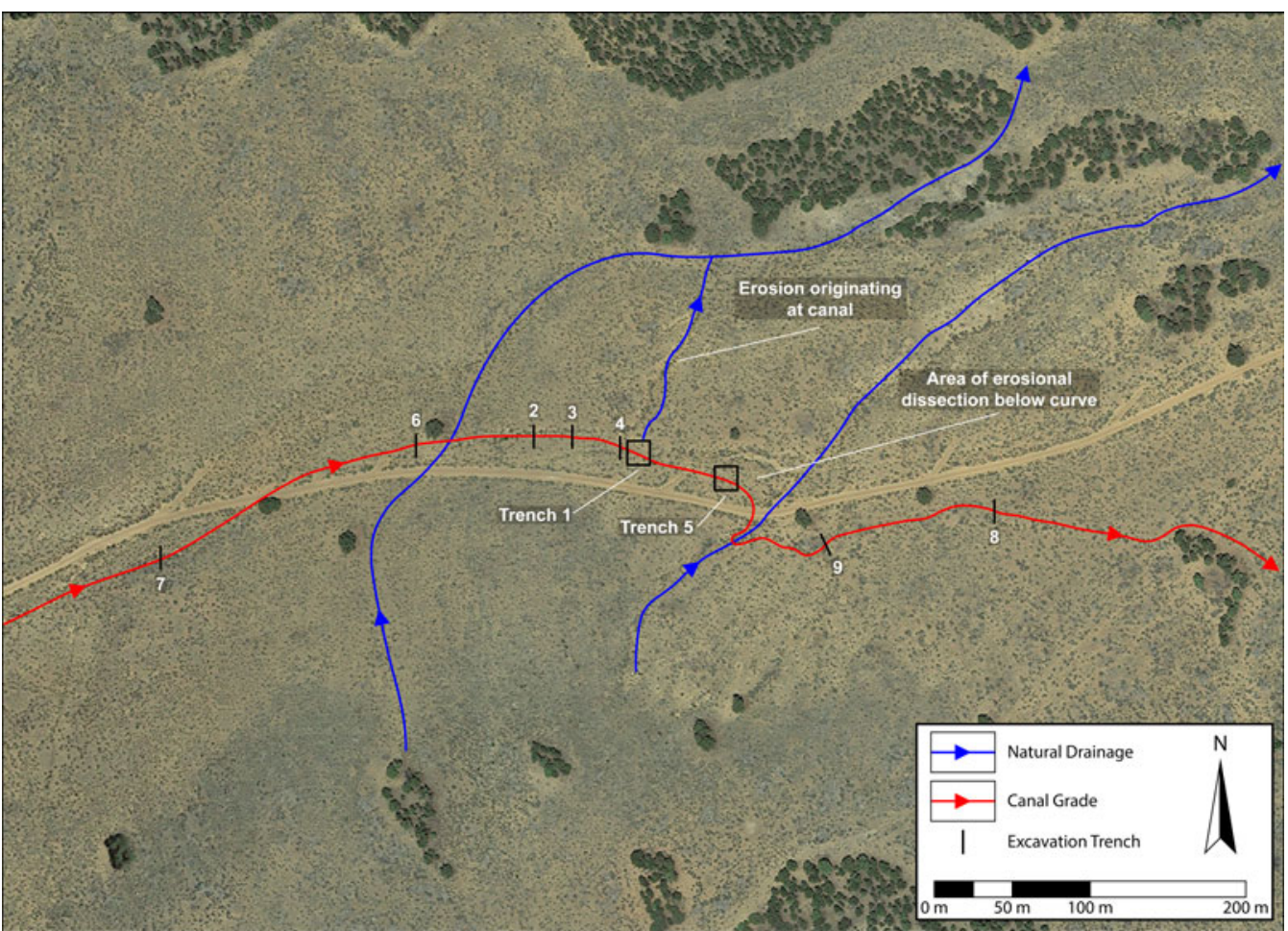

Figure 5. Map showing excavation units and features discussed in text.

Table 1. Optically Stimulated Luminescence (OSL) Age Information (Ordered by Trench and Depth).

\begin{tabular}{lccccccc}
\hline $\begin{array}{l}\text { Sample } \\
\text { No. }\end{array}$ & $\begin{array}{c}\text { USU } \\
\text { No. }\end{array}$ & $\begin{array}{c}\text { Depth } \\
(\mathrm{m})\end{array}$ & $\begin{array}{c}\text { Num. of } \\
\text { Grains }^{\mathrm{a}}\end{array}$ & $\begin{array}{c}\text { Dose Rate } \\
(\mathrm{Gy} / \mathrm{ka})\end{array}$ & $\begin{array}{c}\text { Equivalent Dose }^{\mathrm{b}} \\
\left(\mathrm{D}_{\mathrm{E}}\right) \pm 2 \sigma(\mathrm{Gy})\end{array}$ & $\begin{array}{c}\text { OSL Age } \pm 1 \sigma \\
(\mathrm{ka})\end{array}$ & $\begin{array}{c}\text { OSL Age } \pm 1 \sigma \\
(\mathrm{AD} / \mathrm{BC})\end{array}$ \\
\hline Trench 1 & 1844 & 0.45 & $113(1200)$ & $2.88 \pm 0.13$ & $0.47 \pm 0.15$ & $0.16 \pm 0.03$ & $1850 \pm 30 \mathrm{AD}$ \\
Trench 5 & 1567 & 0.33 & $90(1500)$ & $2.51 \pm 0.11$ & $0.32 \pm 0.12$ & $0.13 \pm 0.03$ & $1880 \pm 30 \mathrm{AD}$ \\
Trench 5 & 1351 & 0.35 & $66(1100)$ & $2.66 \pm 0.12$ & $0.53 \pm 0.29$ & $0.20 \pm 0.06$ & $1810 \pm 60 \mathrm{AD}$ \\
Trench 5 & 1568 & 0.48 & $156(1700)$ & $2.43 \pm 0.11$ & $0.34 \pm 0.12$ & $0.14 \pm 0.03$ & $1870 \pm 30 \mathrm{AD}$ \\
Trench 5 & 1566 & 0.90 & $100(700)$ & $2.56 \pm 0.12$ & $1.23 \pm 0.29$ & $0.48 \pm 0.07$ & $1530 \pm 70 \mathrm{AD}$ \\
Trench 5 & 1845 & 1.25 & $17(29)^{\mathrm{c}}$ & $2.09 \pm 0.09$ & $32.19 \pm 7.33^{\mathrm{d}}$ & $15.39 \pm 2.30$ & $13,380 \pm 2300 \mathrm{BC}$ \\
Trench 9 & 2383 & 0.50 & $77(1800)$ & $3.72 \pm 0.17$ & $0.49 \pm 0.22$ & $0.13 \pm 0.03$ & $1880 \pm 30 \mathrm{AD}$ \\
\hline
\end{tabular}

${ }^{a}$ Age analysis using the single-aliquot regenerative-dose procedure of Murray and Wintle (2000) on single-grains of quartz sand (Duller 2008), unless otherwise noted. Number of grains used in age calculation and number of grains analyzed are in parentheses. Datum for OSL ages is AD 2010.

${ }^{b}$ Equivalent dose $\left(D_{E}\right)$ calculated using the minimum age model of Galbraith and Roberts (2012), unless otherwise noted. See Figure 6 displaying the $\mathrm{D}_{\mathrm{E}}$ distributions for each sample.

${ }^{c}$ Age analysis using the single-aliquot regenerative-dose procedure of Murray and Wintle (2000) on $1 \mathrm{~mm}$ small-aliquots of quartz sand. Number of aliquots used in age calculation and number of aliquots are analyzed in parentheses.

${ }^{\mathrm{d}} \mathrm{D}_{\mathrm{E}}$ calculated using the central age model of Galbraith and Roberts (2012).

ideal for OSL dating. Quartz was used for dating at the Utah State University Luminescence Laboratory, Logan. See Table 1 for ages, Table 2 for dose rates, and Supplemental Materials Section 1 for radial plots.
Eight of the nine trenches were placed on linear sections of canal. All eight exposed a redundant stratigraphic sequence exemplified by Trench 1: a lower, u-shaped channel that is 30 $\mathrm{cm}$ wide $\times 20-25 \mathrm{~cm}$ deep and constructed for 
Table 2. Dose Rate Information (Ordered by USU Lab Number).

\begin{tabular}{lccccccc}
\hline USU No. & Grain Size $(\mu \mathrm{m})$ & $\mathrm{K}(\%)^{\mathrm{a}}$ & $\mathrm{Rb}(\mathrm{ppm})^{\mathrm{a}}$ & $\begin{array}{c}\mathrm{Th} \\
(\mathrm{ppm})^{\mathrm{a}}\end{array}$ & $\begin{array}{c}\mathrm{U} \\
(\mathrm{ppm})^{\mathrm{a}}\end{array}$ & Cosmic $(\mathrm{Gy} / \mathrm{ka})^{\text {Total Dose Rate }(\mathrm{Gy} / \mathrm{ka})^{\mathrm{b}}}$ \\
\hline $1351^{\mathrm{c}}$ & $125-212$ & $1.70 \pm 0.04$ & $72.4 \pm 2.9$ & $8.3 \pm 0.7$ & $2.5 \pm 0.2$ & $0.31 \pm 0.03$ & $2.66 \pm 0.12$ \\
1566 & $90-180$ & $1.57 \pm 0.04$ & $62.5 \pm 2.5$ & $5.8 \pm 0.5$ & $1.7 \pm 0.1$ & $0.29 \pm 0.03$ & $2.56 \pm 0.12$ \\
$1567^{\mathrm{c}}$ & $125-250$ & $1.47 \pm 0.04$ & $59.6 \pm 2.4$ & $5.8 \pm 0.5$ & $1.6 \pm 0.1$ & $0.31 \pm 0.03$ & $2.51 \pm 0.11$ \\
$1568^{\mathrm{c}}$ & $125-250$ & $1.38 \pm 0.04$ & $56.9 \pm 2.3$ & $4.4 \pm 0.4$ & $1.2 \pm 0.1$ & $0.30 \pm 0.03$ & $2.43 \pm 0.11$ \\
& & $1.85 \pm 0.05$ & $78.4 \pm 3.1$ & $10.3 \pm 0.9$ & $3.3 \pm 0.2$ & & $2.88 \pm 0.13$ \\
$1844^{\mathrm{d}}$ & $125-212$ & $1.46 \pm 0.04$ & $59.0 \pm 2.4$ & $4.5 \pm 0.4$ & $1.3 \pm 0.1$ & $0.30 \pm 0.03$ & \\
& & $1.50 \pm 0.04$ & $59.1 \pm 2.4$ & $4.2 \pm 0.4$ & $1.2 \pm 0.1$ & & $2.09 \pm 0.09$ \\
1845 & $125-212$ & $1.49 \pm 0.04$ & $55.7 \pm 2.2$ & $3.5 \pm 0.3$ & $0.8 \pm 0.1$ & $0.28 \pm 0.03$ & $3.72 \pm 0.17$
\end{tabular}

${ }^{a}$ Radioelemental concentrations determined by ALS Chemex using ICP-MS and ICP-AES techniques; dose rate is derived from concentrations by conversion factors from Guérin et al. (2011).

${ }^{\mathrm{b}}$ Assumed $5 \pm 2 \%$ for moisture content over burial history.

${ }^{c}$ Dose rate uses weighted average of radioelemental concentrations from samples within the same sand lens: $50 \%$ from primary sample; 25\% weight for each additional sample (USU-1351, USU-1567, USU-1568).

${ }^{\mathrm{d}}$ Dose rate uses weighted average of radioelemental concentrations: $50 \%$ from primary; $25 \%$ for above and below (ordered respectively).

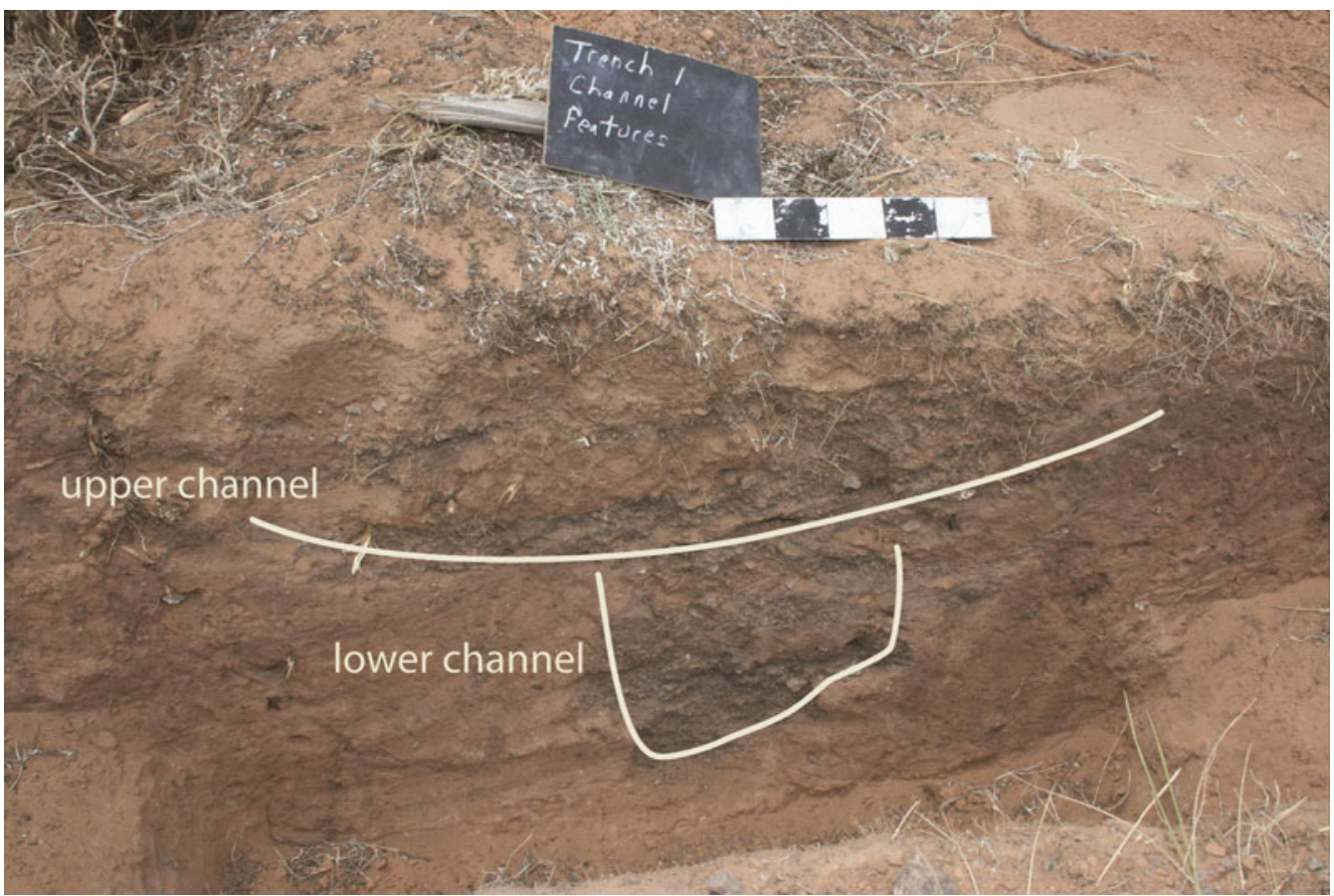

Figure 6. Trench 1 profile showing (a) lower U-shaped channel constructed for irrigation, and (b) upper, saucer-shaped channel from drainage after abandonment and sedimentation. (Color online)

irrigation, overlain by an upper saucer-shaped feature with sediments consistent with natural runoff down a filled canal grade (Figure 6).

The morphology of the U-shaped channel indicates it is anthropogenic. It has vertical walls, constructional gouges inconsistent with natural formation, and bedded fine sediments at the base. In Trench 1, this channel was excavated horizontally exposing $3 \mathrm{~m}$ of its length, a grade of $2 \%$, and a gently undulating floor that contain 
pockets of sand deposits, indicating slowmoving water. An OSL age from these sediments in Trench 1 constrained the timing of last use to AD 1820-1880 (USU-1844). An identical stratigraphic sequence in Trench 9, $100 \mathrm{~m}$ downstream, produced a similar OSL age on basal canal sediments of AD 1850-1910 (USU-2383).

Trench 1 also exhibits a convex berm resulting from canal clean-out. It is adjacent to and downslope from the U-shaped irrigation canal, and it originates on the same surface-below the upper saucer-shaped feature. The berm had been topped and eroded by overbank flow from the canal to form a microdrainage originating at the canal, further supporting the anthropogenic origins (see Figure 5).

Trench 5 departed from the depositional sequence described above because it was placed on a bend in the canal alignment to approach a drainage (Figures 5 and 8). Higher maintenance is inherent along curves where the outer wall of the canal is subject to erosion. Erosional dissection downslope from Trench 5 indicates that water escaped the canal along this bend (Figure 5).

Trench 5 began as a $50 \mathrm{~cm}$ wide $\times 2 \mathrm{~m}$ long trench, which eventually expanded and deepened to $1.2 \mathrm{~m}$ to expose a complex stratigraphy sequence not seen in other trenches (Figure 7). An upper depositional package labeled "historic canal deposits" represents at least two historic irrigation events. Below it is an anthropogenic fill package, and below that are prehistoric canal deposits preserving a single event. Below these, an undated $\mathrm{V}$-shaped channel at the base of the sequence represents natural erosion into Pleistocene deposits. Interspersed between the lower and upper canal deposits are periods of natural deposition and erosion/disturbance. It remains possible that more canal events/deposits were present at one time but have eroded away.

Trench 5 was expanded first by pushing the profile east for $50 \mathrm{~cm}$, progressively exposing a greater extent of sands associated with the canal events seen in profile. A horizontal excavation in Trench 5 targeted the prehistoric canal
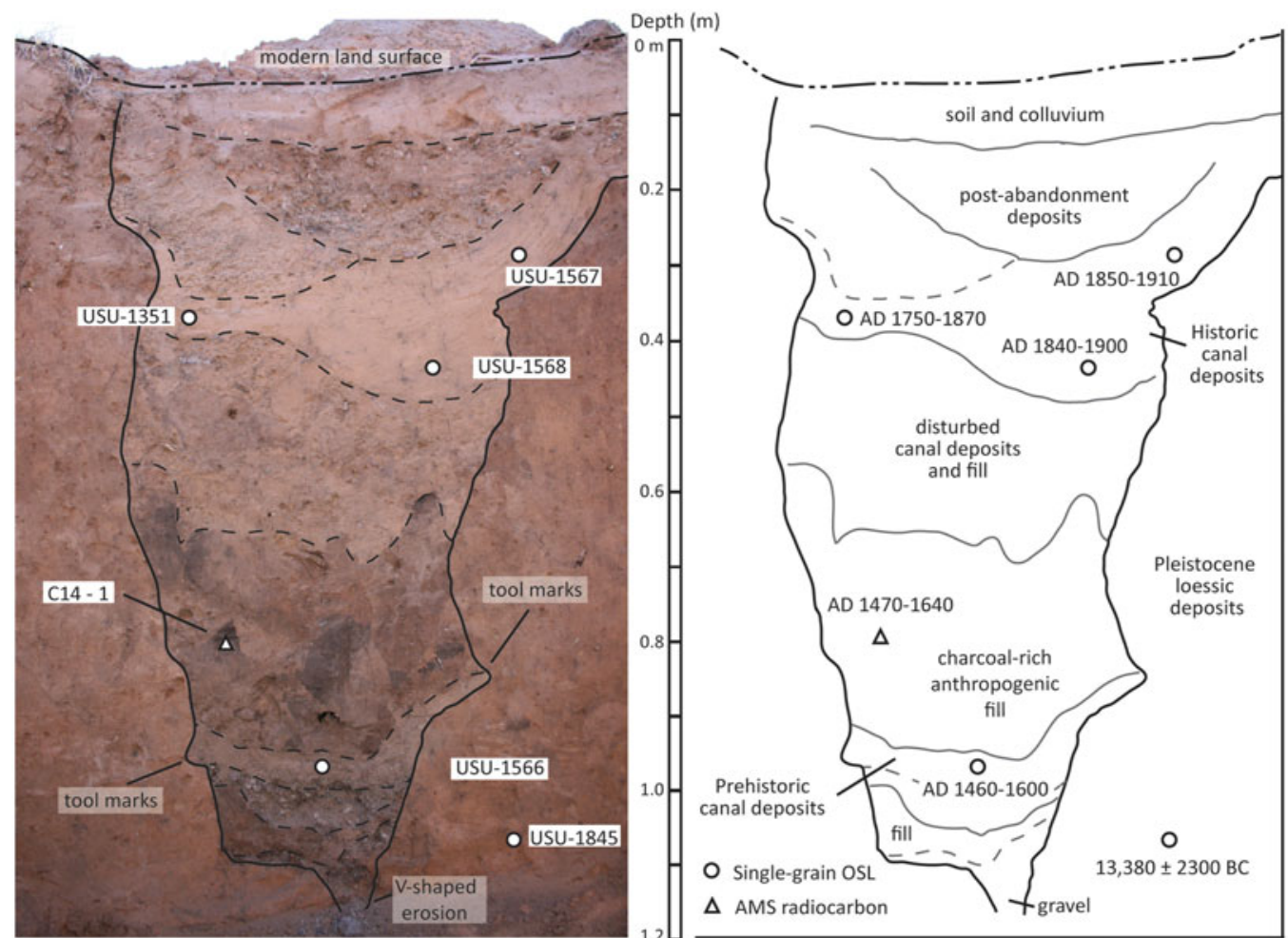

Figure 7. Trench 5 profiles showing features described in text. 


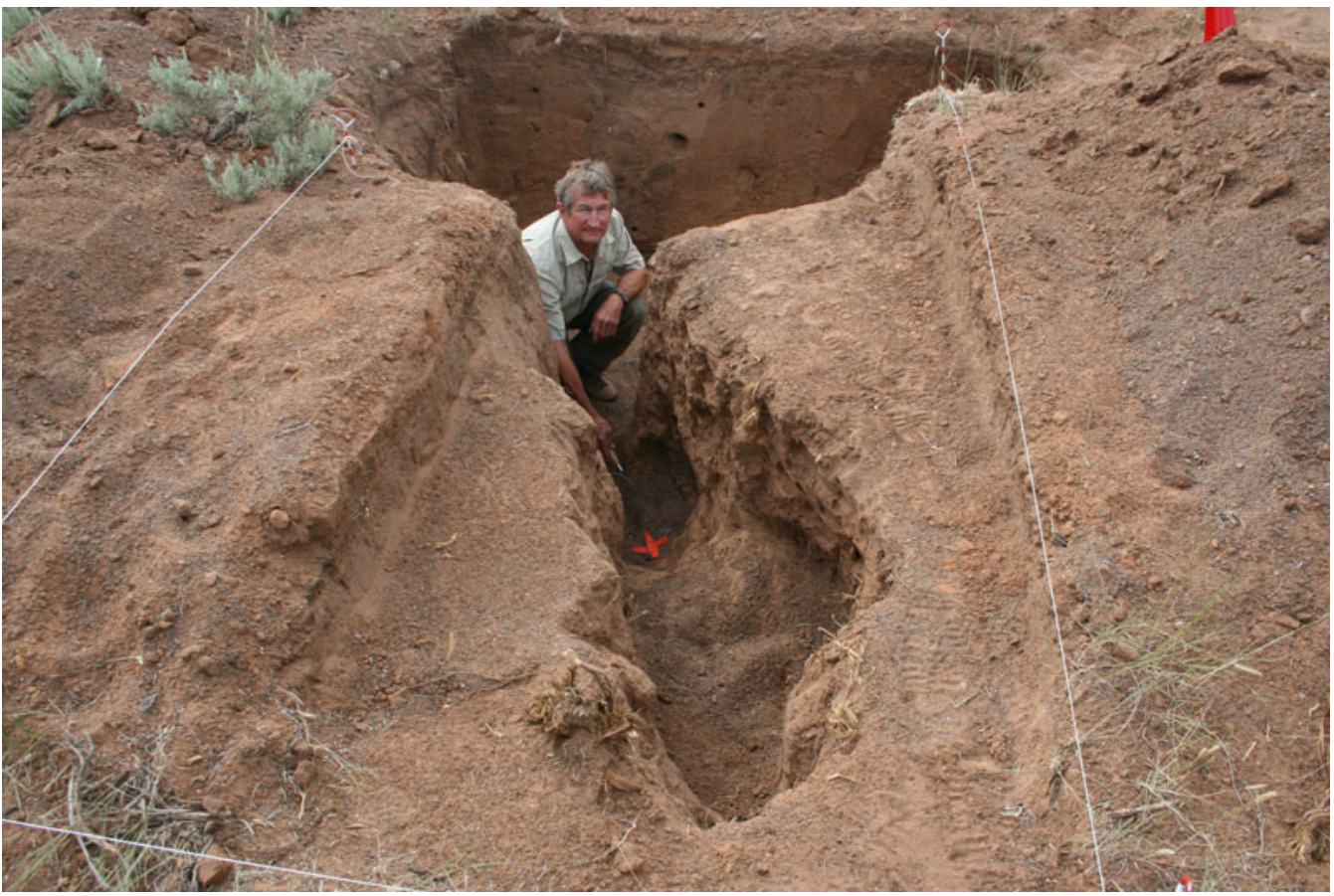

Figure 8. Horizontal excavation of prehistoric canal in progress. (Color online)

deposits and followed the canal west for $3.5 \mathrm{~m}$, upstream toward Trench 1 (Figure 8). Canal morphology is consistent with a constructed channel: vertical sidewalls, angular and scoopshaped cuts, and a flat and gently undulating floor. The prehistoric canal was constructed into an existing canal that became incised by fluvial scour, and it was repaired and reused. Apparently, bank instability along the curve near Trench 5 required multiple episodes of repair and changes in grade. The horizontal excavation of the prehistoric canal exhibited variations in grade, but the western extent of this excavation intercepted the projected grade trending down from Trench $130 \mathrm{~m}$ to the west.

The sequence and chronology of events in Trench 5 (Figure 7) begins with a natural $\mathrm{V}$-shaped erosional channel filled with mixed gravels and sands and located at a depth of 1.2 $\mathrm{m}$. This channel was incised into the sterile substrate, solidified Pleistocene loessic deposits that have been OSL dated to $13,380 \pm 2300 \mathrm{BC}$ (USU-1845). The formation of this erosional channel suggests that an earlier canal existed at this site prior to the deposition of the sequence in Trench 5 that we observe today. This erosional event would have disturbed or removed previously deposited canal sediments. The event may precede preserved use-events by only a short time, but a lack of datable deposits preserved following this erosion makes it impossible to determine when the canal was first constructed.

After a period of unknown duration, the prehistoric canal deposits represent a use-event in a canal similar in size and morphology to the others we identified in both this trench and others. The basal sediments in the prehistoric canal deposits are fine- to medium-laminated sands derived from the abundant exposures of Navajo sandstone in the area. An OSL sample was collected from these sediments at $98 \mathrm{~cm}$ below surface, and it produced an age of $\mathrm{AD}$ 1460-1600 (USU-1566).

Above the prehistoric canal deposits, between 75 and $95 \mathrm{~cm}$ below surface, is the Anthropogenic Fill, a depositional package consisting of angular and irregularly placed clumps of mixed sediments that contain ash and charcoal. This chaotic deposit appears to be anthropogenic 
and may represent an effort to fill and regrade the canal. The sediments were likely collected from the surrounding ground surface, along with charcoal, given that the area around Trench 5 yields archaeological charcoal/ash sediments and ground stone artifacts. The charcoal found in the Anthropogenic Fill were angular uneroded fragments, indicating they had neither been subject to alluvial transport nor found in alluvial sediments. A single piece of charcoal from this deposit $80 \mathrm{~cm}$ below surface, $18 \mathrm{~cm}$ above the OSL sample from the prehistoric canal deposits, was collected for AMS ${ }^{14} \mathrm{C}$ dating and yielded an age of $340 \pm 25 \mathrm{yr}$ BP (UCIAMS-147406) that calibrates to AD 1473-1636 ( $2 \sigma$ age range, IntCal13 database). This radiocarbon age is statistically identical to the OSL age from the prehistoric canal deposits, and taken together, the ages provide evidence for irrigation activities between AD 1460 and 1636.

Above the Anthropogenic Fill is a period of nonuse consisting of disturbed deposits of gravels and unsorted sands. Above that is the fill package of historic canal deposits representing a minimum of two historic irrigation events. Seen only in profile in Trench 5, the walls of the canals display cutmarks and angular gouges as well as near-vertical side walls unlike those that would be formed naturally (Figure 7). Three OSL samples collectively yielded an age range of AD 1750-1910 (USU-1351, USU1567, USU-1568), but one date (USU-1351) is an outlier and was the first sample aged from the profile taken several years before the remaining samples were recovered. Above these canal deposits is the characteristic saucer-shaped feature seen in all the excavations that is caused by natural runoff down the abandoned and filled canal. This is topped by weakly cemented surface sands.

Trench 5 shows that the system experienced repeated use and maintenance, despite the simple stratigraphic sequence seen in the linear sections of canal where previous use-events were not preserved (e.g., Trench 1). Excavation and remote sensing were used to test for the possibility of adjacent channels, but no other channels were found.

Trench 5 provided a rare opportunity to capture the remnants of an earlier canal and use-event. Obliteration of earlier events is typical of irrigation-canal site formation, but this is especially true in a system like Pleasant Creek-an expedient mountain irrigation system that perhaps was only used occasionally and briefly for each event.

\section{Remote Sensing}

A magnetic gradiometer survey on Jorgenson Flat (Figures 2 and 4) explored whether the distribution of water to the agricultural field was engineered with canals, berms, terraces, or dams. Water entered Jorgenson Flat via a natural drainage, about $0.5 \mathrm{~km}$ downstream from the lowest constructed segment of canal. We placed $1120 \times 20 \mathrm{~m}$ blocks on upper Jorgenson Flat (Figure 9) and surveyed using a Geoscan Research FM256 Fluxgate gradiometer, with $0.25 \mathrm{~m}$ transects, collecting data readings every $0.12 \mathrm{~m}$ along each transect. The magnetic gradiometer survey detected ephemeral water flows and prominent sheet-wash events. We did not identify engineered features. Instead, the movement of water appears to have relied on naturally occurring channels fanning out across the field. Hand-excavation trenches bisected several of these (Figure 9), confirming the absence of constructed features.

Magnetic gradiometer and ground penetrating radar (GPR) were also employed adjacent to and south of Trench 5 (Figure 5) to prospect for the canals seen in the excavations. We surveyed two $20 \times 20 \mathrm{~m}$ adjacent blocks using $0.25 \mathrm{~m}$ transects, collecting data every $0.12 \mathrm{~m}$ along a transect between Trenches 1 and 5. The survey detected the course of the canal seen in the excavations, but when other indications were tested with excavation, no other canals were found.

GPR survey was severely limited by vegetation, but the plan view perspective detected the buried canal known through excavation, indicating some utility for imaging and mapping irrigation features.

\section{Agricultural Economics}

We report the results of a study by Kuehn (2014) using experimental archaeology to explore the trade-offs between maintenance and capital 


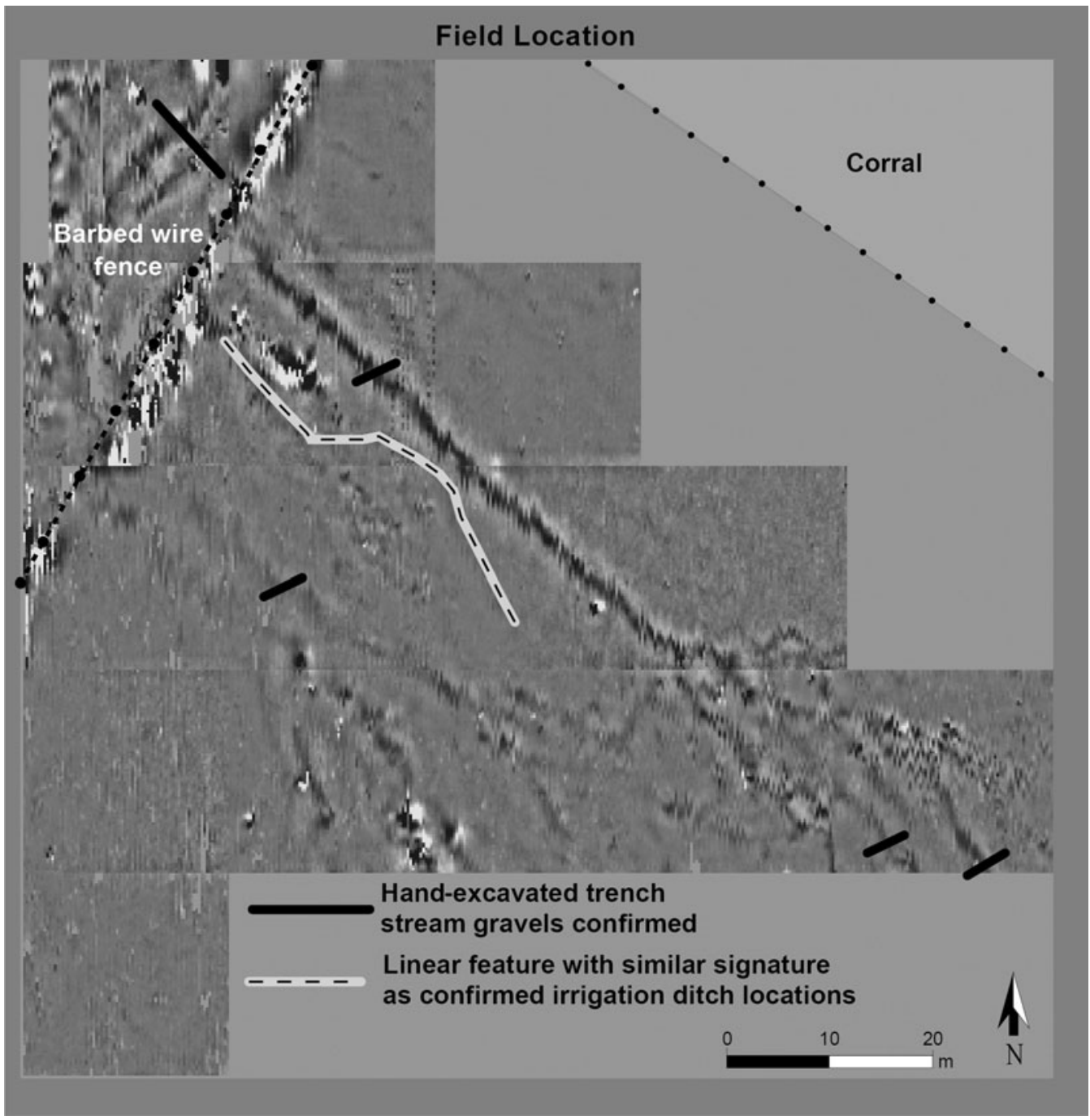

Figure 9. Magnetic gradiometer image of Jorgenson Flat at terminus of canal. Blocks surveyed in $20 \mathrm{~m}$ squares are evident. Dendritic patterns indicate water flowed naturally onto the sloping flat. Linear feature remains unconfirmed.

costs of the Pleasant Creek irrigation system and the costs and benefits of irrigation farming relative to other methods.

Field experiments in 2012-2013 assessed costs by digging segments of irrigation canal using simple wooden digging sticks in soil types that included loose sands, rocky areas with sands and gravels, and loess deposits across landscape positions found along the extent of the canal. Experiments also modeled use and maintenance by constructing canals, rock dams, and barriers; applying water to the experimental segments; and returning a year later to examine the wear and tear (see Kuehn [2014] for methods and detailed descriptions; see Supplemental Materials Section 3 for photos of some experiments).

The resulting labor rate for canal construction and maintenance at $1 \mathrm{~m}^{3} /$ person/day falls within the range of experimental excavation rates reported elsewhere (Barlow 2002; Billman 2002; Erasmus 1965; Mabry 2008; Ortloff et al. 1985; Woodbury 1961). Additional costs such as field labor, harvest, and processing are 


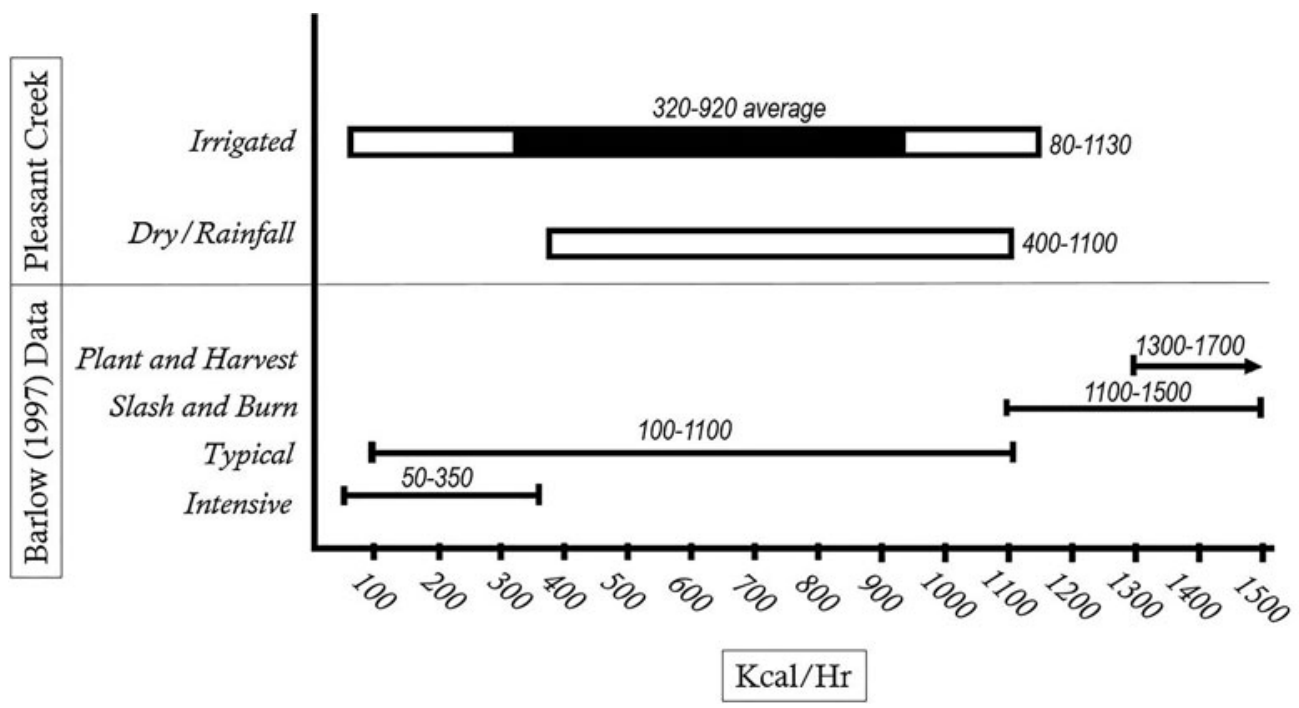

Figure 10. Comparison of the costs of irrigated and dry-farmed maize and other methods. The 320-920 kcal/hr "average" for irrigation farming reflects moderate costs and productivity at field sizes of 10-15 ha.

known from ethnographic contexts (Arbolino 2001; Barlow 1997; Herhahn and Hill 1998; Mabry 2002, 2005). The combined costs of these variables applied to the Pleasant Creek system are 180-560 hours/ha, a broad figure intended to encompass high variability in annual maintenance and field size.

The ethnographic sources above also show how environmental factors of field location related to elevation, summer precipitation, and soil type, as well as estimated irrigation system capacity, influence productivity. The Utah Water Research Laboratory at Utah State University provided a means to estimate the acreage that could be supplied by the Pleasant Creek system onto the unconsolidated $50 \mathrm{~cm}+$ deep sands of Jorgenson Flat. The canal transported a maximum of $0.06 \mathrm{~m}^{3} / \mathrm{second}$ of water. Running 24 hours a day, 36 ha of Jorgenson Flat could be irrigated to 1 acre-foot of water in a month.

The estimated yield for this high-elevation, irrigated maize field is $0.27-0.54 \mathrm{t} / \mathrm{ha}$ (tons/ hectare) compared to $0.07-0.34 \mathrm{t} / \mathrm{ha}$ for nonirrigated maize under similar conditions. Converting these data to $\mathrm{kg} / \mathrm{ha}$, the range developed by Kuehn (2014:61; 4-25 bushels/acre) of $100-625 \mathrm{~kg} / \mathrm{ha}$ corresponds with experiments in
Range Creek Canyon, Utah, of $<100-625 \mathrm{~kg} / \mathrm{ha}$ (Boomgarden et al. 2019:10; Figure 4).

The Pleasant Creek system minimized capital costs while accepting higher maintenance costs. But irrigation farming yields higher productivity per hectare than rainfall farming. Furthermore, the capital costs of construction are amortized over time, which favors redundant use. Maintenance costs of the canal are persistent but mitigated by increasing field size to the point where fields over 10 ha approach full mitigation of maintenance costs. Consequently, irrigation favors larger fields.

Costs of canal construction and maintenance remain subordinate to those of field preparation, planting, harvest, and processing, which dominate the labor associated with all farmingirrigated or rainfall/dry. Therefore, the inclusive energetic return rate for maize irrigation agriculture at Pleasant Creek is 320 and 920 $\mathrm{kcal} / \mathrm{hr}$ (Figure 10)—within the cost envelope of other methods of maize farming (Kuehn 2014:84-87). Irrigation farming should be in the adaptive mix where suitable topographic and hydrological conditions are available. The competitive cost suggests that irrigation offers a hedge against the risk of total crop failure, perhaps making risk reduction more relevant 
than cost in the decision to build and maintain an irrigation system.

\section{Discussion and Implications}

\section{Chronology and Culture History}

The earliest dated irrigation event at the Pleasant Creek site is AD 1460-1636. We present evidence for the existence of an earlier canal, but we cannot date the original construction.

Prehistoric farming north of the Colorado River is conventionally attributed to the Fremont or Ancestral Puebloan, and both declined after AD 1300. The archaeology near the Pleasant Creek site and downstream in Capitol Reef NP is strongly Fremont, but a $30-40 \mathrm{~km}$ walk south finds Fremont/Ancestral Puebloan interaction and joint use (Searcy and Talbot 2015; Talbot 2015, 2019).

The Pleasant Creek site highlights the understanding among archaeologists that the demise of farming was "gradual" (Talbot 2019:43) and "was neither temporally uniform nor were the results everywhere similar" (Lindsay 1986:231).

Fremont presence wanes after AD 1300, but there is an increasing inventory of late dates on Fremont cultural materials. Most are in northeastern Utah and northwestern Colorado, where sites dating to AD 1420-1550 include 42DA791 (Johnson and Loosle 2002), Texas Creek Overlook, the Edge Site, 42UN1103, and 5MF373 (Creasman and Scott 1987). Dates in the AD $1500 \mathrm{~s}$ in the Tavaputs Plateau region of central Utah include a corncob from a rockshelter (42CB224) in Rock Creek canyon, supported by a similar date from a granary $400 \mathrm{~m}$ away (Spangler 2013; Spangler and Aton 2018:149). These cases do not establish that the AD 1460-1636 irrigation event at Pleasant Creek was Fremont.

The prehistoric irrigation event at Pleasant Creek could also be attributed to Ute-Southern Paiute since convention tends to pair that language/ethnic group with the Late Prehistoric age of the irrigation. Ute-Southern Paiute people did farm in the early historic period in lower deserts of extreme southwest Utah and southern Nevada, but only one of 109 sites in the vicinity of Pleasant Creek is identified as Late Prehistoric.
The most recent irrigation events at the Pleasant Creek site are aged by three OSL samples bracketing AD 1750-1910. The potential for partial bleaching of earlier sediments implies events are later in this range, possibly accommodating the early twentieth-century irrigation to which Morss referred. A case for Spanish irrigation seems weak because there is no known Spanish presence in the isolated and rugged canyons near Capitol Reef. The earliest recorded Spanish presence north of the Colorado River is the Dominguez-Escalante Expedition of 1776, which did not come near this area. It only traversed the region and did not result in Spanish settlement (Bolton 1972).

\section{Agricultural Economics and Paleoclimate}

Prehistoric irrigation between AD 1460 and 1636 falls within the Little Ice Age (LIA). Decreasing temperatures on a century scale are significant to the decline in agriculture on the northern Colorado Plateau (Thomson et al. 2019). Yet the climatic variability of the preceding Medieval Climatic Anomaly (MCA) continued during the LIA with "substantial decadal-scale variability" (Salzer and Kipfmueller 2005:473; Figure 4). During the 180-year window for the prehistoric irrigation event at Pleasant Creek, there were four moist intervals and four dry intervals, each a decade or more in duration (Knight et al. 2010:111; Figure 6).

Farming did not disappear from the Puebloan world during the LIA, but rather the distribution of farming changed. On the northern Colorado Plateau, a "drop in mean annual temperature at the MCA-LIA transition was more keenly felt" (Thomson et al. 2019:97). Also, the higher latitudes north of the Colorado River exhibit a weaker North American Monsoon). Modern precipitation data shows that stations in central and northeastern Utah receive $20 \%-40 \%$ less August/September rainfall than stations in northeastern Arizona and northwestern New Mexico. Our evaluation of agricultural economics suggests that an investment in irrigation hedges against the risk of total crop failure from a paucity of summer rain. The higher per-hectare productivity of irrigated maize may have been less significant than the reduction in risk. The benefits of irrigation may increase where the 
summer monsoon is weakest, or most variable: north of the Colorado River. This applies to irrigation during not only the LIA but also the MCA.

We predict that irrigation should be present across much of Utah where there is perennial water, topography conducive to constructing water transport, and potential field areas. Surely irrigation was part of a diversified agricultural adaptive strategy that also included dry farming in various situations to create a "portfolio of arable plots knitted together by kin, cooperation, alliance, conflict, and mobility across the landscape" (Simms 2010:38). Prehistoric irrigation should be more common than we thought. That we do not find it suggests that it is obscured by site formation processes (irrigation events destroy earlier events, urbanization, etc.), but it also goes unrecognized using traditional archaeological search images.

\section{Broader Implications}

Our late dates for irrigation exemplify the fragmentary, shifting nature of agriculture, an enduring pattern that continued even after subregions such as the Mesa Verde and the Great Sage Plain of southwest Colorado/southeast Utah as well as the Fremont of Utah experienced reduced population.

We emphasize here that we cannot ascribe the irrigation event at Pleasant Creek of AD 1460 1636 to a culture, language, or ethnic group, but we also suggest that doing so may constrain a more dynamic perspective. The region north of the Colorado River was occupied by Numicspeaking peoples during the early historic period, yet we know little about the 500 years of preceding history on the northern periphery. The situation begs for a perspective where nonPuebloan peoples interacted with Ancestral Puebloan/Fremont peoples, not only via the wellworn metaphor of "trade and exchange" or the culturally biased term "intermarriage" but also through residential cycling fostering cultural integration and behavioral plasticity over the life histories of individuals (Rushforth and Upham 1992:47-67; Simms 1999; Upham 1994a, 1994b). These references show this concept is not new, and recent efforts envision a milieu of farmers in pueblos, villages, and hamlets among a diversity of lifeways and identities - the "fierce and indomitable" nonPuebloan peoples who may have long histories in the Southwest (Seymour 2017). Recent essays targeting the northern periphery explore interaction across boundaries of identity and ethnicity (Ahlstrom 2015; Roberts 2017). Identity is circumstance dependent-potentially pliant or resistant-and maintenance of identity may occur under conditions of considerable residential cycling and cultural association.

Irrigation at Pleasant Creek between AD 1460 and 1636 is a mundane symbol of not only cultural continuity between the ancient and modern tribes but a perspective that substitutes bounded archaeological taxonomies with a more behaviorally realistic view in which life history interaction and residential cycling blur the lines among all descendants of the ancients during periods of upheaval, reorganization, and population displacement.

Supplemental Material. For supplementary material accompanying this article, visit https://doi.org/10.1017/aaq.2020.25.

Section 1. OSL Radial Plots.

Section 2. Photos of canal, excavation, and location/maps. Section 3. Photos of experimental archaeology.

Section 4. Selected topical photos.

Section 5. Examples of historic use built after the construction of Lower Bowns Reservoir in the 1920s and 1930s.

Acknowledgments. We gratefully acknowledge the support of the Committee for Research and Exploration of the National Geographic Society as well as the College of Humanities and Social Sciences and the Department of Biology at Utah State University. OSL dating was done by the Utah State University Luminescence Laboratory. Thanks to the Dixie and Fishlake National Forests: Kurt Robins, Robert Leonard, and Marian Jacklin. Thanks to Arie Leeflang, records manager Antiquities Section at Utah Division of State History, and to Dr. Mac McKee and Steven Barfuss of the Utah Water Research Laboratory at Utah State University. Comments by Jack Broughton, Kristen Hawkes, Duncan Metcalfe, and anonymous reviewers improved this article. Thanks to Aaron Larson for drafting and to the 15 student volunteer fieldworkers.

Data Availability Statement. No original data were presented in this article.

\section{References Cited}

Ahlstrom, Richard V. N.

2015 Prehistoric Hunter-Gatherer-Farmer Identities in Las Vegas Valley, Southern Nevada. In Interaction and Connectivity in the Greater Southwest, edited by 
Karen G. Harry and Barbara J. Roth, pp. 329-352. University Press of Colorado, Louisville.

Arbolino, Risa Diemond

2001 Agricultural Strategies and Labor Organization: An Ethnohistoric Approach to the Study of Prehistoric Farming Systems in the Taos Area of Northern New Mexico. PhD dissertation, Department of Anthropology, Southern Methodist University, Dallas, Texas. University Microfilms, Ann Arbor.

Barlow, K. Renee

1997 Foragers That Farm: A Behavioral Ecology Approach to the Economics of Corn Farming for the Fremont Case. PhD dissertation, Department of Anthropology, University of Utah, Salt Lake City. University Microfilms, Ann Arbor.

2002 Predicting Maize Agriculture among the Fremont: An Economic Comparison of Farming and Foraging in the American Southwest. American Antiquity 67:65-88.

Billman, Brian R.

2002 Irrigation and the Origins of the Southern Moche State on the North Coast of Peru. Latin American Antiquity 13:371-400.

Bolton, Herbert E.

1972 Pageant in the Wilderness: The Story of the Escalante Expedition to the Interior Basin 1776. Utah State Historical Society, Salt Lake City.

Boomgarden, Shannon A., Duncan Metcalfe, and Ellyse T. Simons

2019 An Optimal Irrigation Model: Theory, Experimental Results, and Implications for Future Research. American Antiquity 84:252-273.

Creasman, Steven D., and Linda J. Scott

1987 Texas Creek Overlook: Evidence for Late Fremont (post A.D. 1200) Occupation in Northwest Colorado. Southwestern Lore 53(4):1-16.

Duller, Geoffrey A. T.

2008 Single-Grain Optical Dating of Quaternary Sediments: Why Aliquot Size Matters in Luminescence Dating. Boreas 37:589-612.

Erasmus, Charles J.

1965 Monument Building: Some Field Experiments. Southwestern Journal of Anthropology 21:277-301.

Galbraith, Rex F., and Richard G. Roberts

2012 Statistical Aspects of Equivalent Dose and Error Calculation and Display in OSL Dating: An Overview and Some Recommendations. Quaternary Geochronology 11:1-27.

Guérin, Guillaume, N. Mercier, and G. Adamiec

2011 Dose-Rate Conversion Factors: Update. Ancient TL 29:5-8.

Gunnerson, James H.

1957 An Archeological Survey of the Fremont Area. University of Utah Anthropological Papers No. 28. University of Utah Press, Salt Lake City.

Herhahn, Cynthia L., and J. Brett Hill

1998 Modeling Agricultural Production Strategies in the Northern Rio Grande Valley, New Mexico. Human Ecology 26:469-487.

Huckleberry, Gary, and Tammy Rittenour

2014 Combining Radiocarbon and Single-Grain Optically Stimulated Luminescence Methods to Accurately Date Pre-Ceramic Irrigation Canals, Tucson, Arizona. Journal of Archaeological Science 41:156-170.

Janetski, Joel C., Lee Kreutzer, Richard K. Talbot, Lane D. Richens, and Shane A. Baker

2005 Life on the Edge: Archaeology in Capitol Reef
National Park. Occasional Paper No. 11. Museum of Peoples and Cultures, Brigham Young University, Provo, Utah.

Johnson, Clay, and Byron Loosle

2002 Prehistoric Uinta Mountain Occupations. Heritage Report 2-02/2002. Ashley National Forest, Intermountain Region, USDA Forest Service. Vernal, Utah.

Knight, Troy A., David M. Meko, and Christopher H. Baisan

2010 A Bimillennial-Length Tree-Ring Reconstruction of Precipitation for the Tavaputs Plateau, Northeastern Utah. Quaternary Research 73:107-117.

Kreutzer, Lee

2005 Archaeological, Historical, and Ethnographic Research at Capitol Reef National Park. In Life on the Edge: Archaeology in Capitol Reef National Park, by Joel C. Janetski, Lee Kreutzer, Richard K. Talbot, Lane D. Richens, and Shane A. Baker, pp. 19-36. Occasional Paper No. 11. Museum of Peoples and Cultures, Brigham Young University, Provo, Utah.

Kuehn, Chimalis R.

2014 The Agricultural Economics of Fremont Irrigation: A Case Study from South-Central Utah. Master's thesis, Department of Sociology, Social Work, and Anthropology, Utah State University, Logan. Graduate Theses and Dissertations, htstp://digitalcommons.usu.edu/etd/3304, accessed April 14, 2020.

Lindsay, Lamar W.

1986 Fremont Fragmentation. In Anthropology of the Desert West: Essays in Honor of Jesse D. Jennings, edited by Carol J. Condie and Don D. Fowler, pp. 229-251. Anthropological Papers 110. University of Utah Press, Salt Lake City.

Lohse, Ernst S.

1980 Fremont Settlement Pattern and Agricultural Variation. In Fremont Perspectives, edited by David B. Madsen, pp. 41-54. Utah State Historical Society, Salt Lake City.

Mabry, Jonathan B.

2002 The Role of Irrigation in the Transition to Agriculture and Sedentism in the Southwest: A Risk Management Model. In Traditions, Transitions, and Technologies: Themes in Southwestern Archaeology, Proceedings of the 2000 Southwest Symposium, edited by Sarah H. Schlanger, pp. 178-199. University Press of Colorado, Boulder.

2005 Diversity in Early Southwestern Farming and Optimization Models of Transitions to Agriculture. In Subsistence and Resource Use Strategies of Early Agricultural Communities in Southern Arizona, edited by Michael Diehl, pp. 113-152. Anthropological Papers No. 34. Center for Desert Archaeology, Tucson, Arizona.

2008 Las Capas: Early Irrigation and Sedentism in a Southwestern Floodplain. Anthropological Papers No. 28. Center for Desert Archaeology, Tucson, Arizona.

Marwitt, John P.

1970 Median Village and Fremont Culture Regional Variation. Anthropological Papers 95. University of Utah Press, Salt Lake City.

Metcalfe, Duncan, and Lisa V. Larrabee

1985 Fremont Irrigation: Evidence from Gooseberry Valley. Journal of California and Great Basin Anthropology 7:244-254.

Morss, Noel

2009 The Ancient Culture of the Fremont River in Utah. Reprinted. University of Utah Press, Salt Lake City. 
Originally published 1931, Peabody Museum of American Archaeology and Ethnology, Harvard University, Cambridge, Massachusetts.

Murray, Andrew S., and Ann G. Wintle

2000 Luminescence Dating of Quartz Using an Improved Single Aliquot Regenerative-Dose Protocol. Radiation Measurements 32:57-73.

Ortloff, Charles R., Robert A. Feldman, and Michael E. Moseley

1985 Hydraulic Engineering and Historical Aspects of the Pre-Columbian Intravalley Canal Systems of the Moche Valley, Peru. Journal of Field Archaeology 12:77-98.

Reagan, Albert B.

1931a Archaeological Notes on the Brush Creek Region, Northeastern Utah. Wisconsin Archaeologist 10:132138

1931b Some Notes on the Ancient Earth-Lodge Peoples of the Willard Stage of Pueblo Culture in the Uintah Basin, Utah. El Palacio 30:236-241.

1931c Early House Builders of the Brush Creek Region of Northeastern Utah. American Anthropologist 33:660 661.

1931d Notes from the Field. Discoveries 2:8. Reagan Papers, Special Collections, H. B. Lee Library, Brigham Young University, Provo, Utah.

1931e Some Archaeological Notes on Nine Mile Canyon, Utah. El Palacio 31:45-71.

1931f Some Archaeological Notes on Hill Canyon in Northeastern Utah. El Palacio 31:223-244.

Reimer, Paula J., Edouard Bard, Alex Bayliss, J. Warren Beck, Paul G. Blackwell, Christopher Bronk Ramsey, Caitlin E. Buck, Hai Cheng, R. Lawrence Edwards, Michael Friedrich, Pieter M. Grootes, Thomas P. Guilderson, Haflidi Haflidason, Irka Hajdas, Christine Hatté, Timothy J. Heaton, Dirk L. Hoffmann, Alan G. Hogg, Konrad A. Hughen, K. Felix Kaiser, Bernd Kromer, Sturt W. Manning, $\mathrm{Mu}$ Niu, Ron W. Reimer, David A. Richards, E. Marian Scott, John R. Southon, Richard A. Staff, Christian S. M. Turney, Johannes van der Plicht

2013 Intcal13 and Marine13 Radiocarbon Age Calibration Curves 0-50,000 Years cal BP. Radiocarbon 55:1869-1887.

Roberts, Heidi

2017 It's Complicated: Discerning the Post-Puebloan Period in Southern Nevada's Archaeological Record. In Fierce and Indomitable: The Protohistoric NonPueblo World in the American Southwest, edited by Deni J. Seymour, pp. 281-300. University of Utah Press, Salt Lake City.

Rushforth, Scott, and Steadman Upham

1992 A Hopi Social History: Anthropological Perspectives on Sociocultural Persistence and Change. University of Texas Press, Austin.

Salzer, Matthew W., and Kurt F. Kipfmueller

2005 Reconstructed Temperature and Precipitation on a Millennial Timescale from Tree-Rings in the Southern Colorado Plateau, U.S.A. Climatic Change 70:465-487.

Searcy, Michael T., and Richard K. Talbot

2015 Late Fremont Cultural Identities and Borderland Processes. In Late Holocene Research on Foragers and Early Farmers in the Desert West, edited by Barbara J. Roth and Maxine E. McBrinn, pp. 234-264. University of Utah Press, Salt Lake City.
Seymour, Deni J.

2017 Fierce, Barbarous, and Untamed: Ending Archaeological Silence on Southwestern Mobile Peoples. In Fierce and Indomitable: The Protohistoric Non-Pueblo World in the American Southwest, edited by Deni J. Seymour, pp.1-15. University of Utah Press, Salt Lake City.

Simms, Steven R.

1999 Chasing the Will-o'-the Wisp of Social Order. In Models for the Millennium: The Current Status of Great Basin Anthropological Research, edited by Charlotte Beck, pp. 105-110. University of Utah Press, Salt Lake City.

2010 Traces of Fremont: Society and Rock Art in Ancient Utah. University of Utah Press, Salt Lake City.

Simms, Steven R., and Jason Bright

2009 Fremont Villages and Complexity: How and Why? Poster presented at the 32nd Biennial Great Basin Anthropological Conference, Layton, Utah. DOI:10.13140/RG.2.2.20963.81449.

Simms, Steven R., and Chimalis Kuehn

2012 The Archaeology of Ancient Fremont Irrigation: Initial Investigations at the Pleasant Creek Site. Report to the Fishlake National Forest, U.S. Forest Service. Utah State Project Number U-12-UJ-0985f. Utah State University, Logan. DOI:10.13140/RG.2.2.10002.20164.

Spangler, Jerry D

2013 Nine Mile Canyon: The Archaeological History of an American Treasure. University of Utah Press, Salt Lake City.

Spangler, Jerry D., and James M. Aton

2018 The Crimson Cowboys: The Remarkable Odyssey of the 1931 Claflin-Emerson Expedition. University of Utah Press, Salt Lake City.

Talbot, Richard K.

2015 The Late Fremont Regional System. In Interaction and Connectivity in the Greater Southwest, edited by Karen G. Harry and Barbara J. Roth, pp. 378-405. University Press of Colorado, Louisville.

2019 Escalante-Area Fremont. Archaeology Southwest $33: 41-43$.

Talbot, Richard K., and Lane D. Richens

1996 Steinaker Gap: An Early Fremont Farmstead. Museum of Peoples and Cultures Occasional Paper No. 2. Brigham Young University, Provo, Utah.

Thomson, Marcus J., Juraj Balkovič, Tamás Krisztin, and Glen M. MacDonald

2019 Simulated Impact of Paleoclimate Change on Fremont Native American Maize Farming in Utah, 850 1449 CE, Using Crop and Climate Models. Quaternary International 507:95-107.

Upham, Steadman

1994a Nomads of the Desert West: A Shifting Continuum in Prehistory. Journal of World Prehistory 8:113-167.

1994b Ten Years After: Adaptive Diversity and Southwestern Archaeology. Journal of Anthropological Research 50:155-157.

Woodbury, Richard B.

1961 A Reappraisal of Hohokam Irrigation. American Anthropologist 63:550-560.

Submitted April 12, 2019; Revised February 23, 2020;

Accepted February 23, 2020 